\title{
Is the Market Efficiency Hypothesis Applicable in the Czech Republic - FOREX Case
}

\author{
Petr Makovský \\ Masaryk Institute of Advanced Studies, Czech Technical University in Prague, Czech Republic
}

Received August 11, 2021; Revised October 21, 2021; Accepted November 11, 2021

\section{Cite This Paper in the following Citation Styles}

(a): [1] Petr Makovský, "Is the Market Efficiency Hypothesis applicable in the Czech Republic - FOREX Case," Universal Journal of Accounting and Finance, Vol. 9, No. 6, pp. 1495-1502, 2021. DOI: 10.13189/ujaf.2021.090626.

(b): Petr Makovsky (2021). Is the Market Efficiency Hypothesis applicable in the Czech Republic - FOREX Case. Universal Journal of Accounting and Finance, 9(6), 1495-1502. DOI: 10.13189/ujaf.2021.090626.

Copyright $(2021$ by authors, all rights reserved. Authors agree that this article remains permanently open access under the terms of the Creative Commons Attribution License 4.0 International License

\begin{abstract}
The Efficient Market Hypothesis (EMH) is the generalization of the so called perfect competition for the financial markets. Sometimes the financial markets are assumed to be the markets most similar to the perfect competition. So, every test of the EMH theory is the test about the perfect competition approach and then its conclusions are about the market mechanisms and potential regulation and policy. Even though, discussions about the financial capital regulations, free movements of financial capital and taxing are widespread, not only in economic theory scientific conferences, but anywhere. The FOREX market is the financial market, in which there is the highest amount of trading, so that we assume the feature analyzed be the most visible. More in the Czech Republic there is permanent question about the pros and cons of the national currency. The EHM theory concluded remarks also influence the discussion. The problem is not so simple. The conclusion is not about the purity of the efficient or inefficient financial markets. The conclusion must be about the level of the market efficiency, which is moreover variable in the different time periods. More we analyzed the effects of the great financial crisis in 2008.
\end{abstract}

Keywords Time Series Analysis, Martingale Stochastic Process, Cointegration, Perfect Competition

\section{Introduction}

In the Czech Republic, we do see many arguments about the regulation of the financial sector or vice versa.
The nonregulated financial sector argues mostly on the base of so-called Fama's Market Efficient Hypothesis (MEH). This hypothesis, its weak form, is about that none is able to achieve abnormal riskless profits by trading. Because the asset prices fully reflect all the previous information [10]. The hypothesis corresponds with the impossibility of the arbitrary profit or the law of one price. In the other words, it is about market equilibrium of the perfect competition on the financial market. More the MEH hypothesis is the joint hypothesis, which makes the problem difficult or even unsolvable [8]. The inefficient financial markets cause rejection of the $\mathrm{MEH}$, or we have assumed incorrect equilibrium model. In other words, to compare market efficiency, we have to construct a model for the expected return of assets and then compare to the real returns. If the model basis is on the market equilibrium, then there is no under or over valuated asset. We have no benchmark to compare because if the asset is not on its equilibrium value we have no model to gain the expected return. We assume only equilibrium values of returns. Finally, therefore the existence of abnormal return confirms the market inefficiency or inappropriate asset pricing model or both. Described critique of the CAPM based asset evaluation and potential testing of MEH starts from the work of Markowitz [23], Tobin [29], Mossin [26], Lintner [18] and more others. The original CAPM deduces the market equilibrium approach, which is the reason of our critique. Investors evaluate financial assets as underestimated, for which there is no reason. Moreover, it assumes the stable systematic risk, which anyone can empirically reject.

Previous critique of empirics is being solved thank to 
the C-CAPM approach, in which we work with the assumption of the representative agent model. Otherwise, Mehra and Prescott [24] rejected the approach due to impossibility to explain the empirical yields in stock prices. Model is able to explain the risk premium only using disproportionately high coefficient of the relative risk aversion. Moreover, we add, that in contrary with previous, using the higher coefficient of risk aversion causes unexplainable evolution of the risk-free rate. This C-CAPM puzzle is originally solved thank to so called Hansen-Jagannathan bounds [12]. Finally, even by using the C-CAPM approach we were unable to confirm MEH theoretically.

Theory explains the existence of the bubbles in the financial markets in a few ways. At first, using the approach of the "technological bubbles" [26]. At second, Aiyagari and Gertler [2] explain bubbles existence of restriction of any financial firm about unlimited financial resources. In the Abreu, Brunnermeier approach [1] the asset bubbles persist even in the presence of the rational arbitrageurs. Bernanke and Gertler [4] explain the existence of bubbles by using the financial accelerator. More, theory bases the explanation on the asymmetric information, difference in productivity of the real firms and the difference in the debts options of firms. These factors in the real economy influence the bubbles persistence in the financial sector.

In this paper, we have chosen the FOREX market efficient hypothesis in the Czech Republic. The reason is the data availability and its structure. We have forward rates and the spot exchange rates available in the Czech National Bank on the data sample of the daily data from 2001 to now. Moreover, the FOREX market is the financial market achieving the highest volumes of trading in the Czech Republic. We have even chosen the FOREX market efficient hypothesis in the Czech Republic because the data sample of rates is available (CNB database) from the 2001 to 2019, The Financial Crisis on September, 2008 divides this evolution into halves so that we are able to make diagnosis of the differences before the crisis 2008 and after.

The economics of the Exchange Rates is based on the (un)covered interest rates parity. In the most simply way, the evolution of spot exchange rate is driven with the interest rates differential and the purchasing power parity - relative version explains the development of the expected exchange rate. Generally, previous two conditions summarize, that the forward rate serves as unbiased predictor of the future spot exchange rate.

\section{Methodology}

This paper follows two ways. First, it is the general economic theory. Second, it is time series analysis modelling the random residual terms. This statistical approach is very useful for analysis of financial time series with stochastic trends. We run many statistical tests on the empirical data sample of the Czech Republic in Eviews software according to methodology ARMA, VAR, (V)EC model and Cointegration. We followed Hamilton [13]. The literature overview is not only Fama [10]. The risk premium puzzle is solved in Wickens [30] or Lucas [19]. The FOREX risk premium is then driven with the covariance of the stochastic discount factor with the exchange rate evolution, and the evolution of inflation rate. Similar conclusions can be found in Cochrane [7] or in Cuthberson [8]. Baillie and Bollerslev [3] and Canova and Ito [6] describe the risk market premium analysis. Betts and Devereux [5] show how presence of the Pricing to the market (PTM) mechanism increases the exchange rates volatility, relative to a situation, where the Law of one price holds.

Kočenda and Poghosyan [16] empirically verified high enough FOREX risk premium in the new EU members. This abnormal premium will be normalized, as soon as the convergence of the economies among the EU. In these new EU members, there appears a significant influence of the money aggregate. Kočenda and Poghosyan [16] explain this effect of the money aggregate to the exchange rates with the influence of the Maastricht criterion and thus fiscal discipline. In the end, there is a conclusion about the importance of the nominal convergence because the nominal factors are the main source of the FOREX risk premium (covariance with the inflation rate). On the basis of Teräsvirta [28] it is used the ESTAR model (Exponencial Smooth Transition Autoregression) as a best way to model the residuals from the MEH. Londono and Zhou [17] made research of the Forward premium puzzle and they concluded that the FOREX appreciation is predictable by the currency variance risk premium at a medium 6-month horizon and by the stock variance risk premium at a short 1-month horizon. The data sample for previous research consists of the US currency rates to Japan, Great Britain and the Euro area. Kočenda and Moravcová [15] divided the period after GFC (2008-09) into two subsamples according to EU debt crisis. They concluded about the declining conditional correlations among the new EU exchange rates prior to both crises. More they document that during calm periods, most of the volatilities are due to each currency's own history.

\section{Inefficient FOREX Market}

The rational economics theory states the present forward rate to be the unbiased predictor of the future spot Exchange rate. The differences between the spot exchange rate and the corresponding lagged forward rate confirm the standard Gauss - Markov assumptions. These residuals must be independent and identically distributed (iid). Historically, there are many empirical studies falsifying 
the so-called Fama's regression. For example, Hansen and Hodrick [12] and Hau [14]. From the Czech economy, it is necessary to list studies mainly from Kočenda and Poghosyan, [16]. The law of one price (LOOP) derives the first formula (1). In the other words, it is no arbitrary opportunity at international deposit market. It is the uncovered interest rates parity. Where $S_{t}$ is the actual exchange rate between domestic and foreign currency, $E_{t}\left(S_{t+k}\right)$ is the expected exchange rate for the future time $k$, $i^{D}{ }_{t+1}$ is the next period interest rate in domestic economy and $i^{F}{ }_{t+1}$ is the next period interest rate in the foreign economy.

$$
\frac{E_{t}\left(S_{t+k}\right)}{S_{t}}=\frac{1+i_{t+1}^{D}}{1+i_{t+1}^{F}}
$$

in logarithmic transformation

$$
E_{t}\left(s_{t+k}\right)-s_{t}=i_{t+1}^{D}-i_{t+1}^{F}
$$

Fama's test is integrated with the covered interest rates (3). Here $f_{t+k}$ is the logarithmic value of forward exchange rate corresponding to the period $k ; a_{0}, a_{1}$ are regression parameters, $v_{t}, \varepsilon_{t}$ is the residual term i.i.d.

$$
\Delta s_{t+k}=a_{0}+a_{1}\left(f_{t+k}-s_{t}\right)+\eta_{t}
$$

Assumed the probability limit of linear parameter $a_{l}$ :

$$
a_{1}=\frac{\operatorname{cov}\left(\Delta s_{t+k}, f_{t+k}-s_{t}\right)}{\operatorname{var}\left(f_{t+k}-s_{t}\right)}
$$

very simple

$$
E_{t}\left(s_{t+k}\right)=f_{t+k}+\varepsilon_{t}
$$

Wickens [29] assumes the time series of FOREX variables to follow the logarithmic - normal probabilistic distribution, if there is risk premium on the FOREX. The C-CAPM approach verifies due to the formula (6). Here there is added $\Delta c_{t+1}$ as a percentage change in macroeconomic consumption in the domestic economy and $\pi_{t+1}$ as next period inflation rate.

$$
\begin{aligned}
& E_{t}\left(\Delta S_{t+1}-i_{t+1}^{D}-i_{t+1}^{F}\right)+\frac{1}{2} V_{t}\left(\Delta s_{t+1}\right)= \\
= & \sigma_{t} \operatorname{cov}_{t}\left(\Delta c_{t+1}, \Delta s_{t+1}\right)+\operatorname{cov}_{t}\left(\pi_{t+1}, \Delta c_{t+1}\right)
\end{aligned}
$$

\section{Data}

Our dataset is time series from the Czech National Bank. The time series are the CZK/EUR spot exchange rate and the $3 \mathrm{M}$ Forward rate CZK/EUR. The data sample range is from the $05 / 2001$ to the $02 / 2019$. In order to achieve better statistical features, we transformed the day-time series into the month averages. For further analysis (better statistical features but with certain economic sense), we used logarithms of the month averages. Totally, our data sample consists of 213 observations.

Table 1. Time series features whole data sample range 213 observations

\begin{tabular}{|c|c|c|c|c|c|}
\hline & Mean & Median & Standard Deviation & Jarque-Bera (p-value) & Unit Root test (p-value) \\
\hline$S_{t}$ & 27,68 & 27,04 & 2,60 & 0,000 & 0,164 \\
\hline$F_{t}$ & 27,68 & 27,04 & 2,61 & 0,000 & 0,153 \\
\hline$S_{t}-F_{t}(-3)$ & $-0,11$ & $-0,70$ & 0,711 & 0,000 & 0,000 \\
\hline$s_{t}=\log \left(S_{t}\right)$ & 3,316 & 3,297 & 0,091 & 0,000 & 0,204 \\
\hline$f_{t}=\log \left(F_{t}\right)$ & 3,316 & 3,297 & 0,091 & 0,000 & 0,191 \\
\hline $\log \left(S_{t}\right)-\log \left(F_{t}(-3)\right)$ & $-0,004$ & $-0,003$ & 0,026 & 0,000 & 0,000 \\
\hline
\end{tabular}

Source: Eviews output

Table 2. Time series features (2001m05 to 2008m09) 89 observations

\begin{tabular}{|c|c|c|c|c|c|}
\hline & Mean & Median & $\begin{array}{c}\text { Standard } \\
\text { Deviation }\end{array}$ & $\begin{array}{c}\text { Jarque-Bera } \\
\text { (p-value) }\end{array}$ & $\begin{array}{c}\text { Unit Root test } \\
\text { (p-value) }\end{array}$ \\
\hline$S_{t}$ & 29,87 & 30,19 & 2,53 & 0,158 & 0,936 \\
\hline$F_{t}$ & 29,86 & 30,17 & 2,57 & 0,180 & 0,938 \\
\hline$S_{t}-F_{t}(-3)$ & $-0,33$ & $-0,28$ & 0,706 & 0,414 & 0,003 \\
\hline$s_{t}=\log \left(S_{t}\right)$ & 3,393 & 3,408 & 0,087 & 0,037 & 0,969 \\
\hline$f_{t}=\log \left(F_{t}\right)$ & 3,393 & 3,407 & 0,088 & 0,047 & 0,970 \\
\hline $\log \left(S_{t}\right)-\log \left(F_{t}(-3)\right)$ & $-0,01$ & $-0,01$ & 0,024 & 0,307 & 0,003 \\
\hline
\end{tabular}

Source: Eviews output 
Table 3. Time series features (2008m10 to2019m02) 124 observations

\begin{tabular}{|c|c|c|c|c|c|}
\hline & Mean & Median & $\begin{array}{c}\text { Standard } \\
\text { Deviation }\end{array}$ & $\begin{array}{c}\text { Jarque-Bera } \\
(\mathbf{p} \text {-value })\end{array}$ & $\begin{array}{c}\text { Unit Root test } \\
(\mathbf{p} \text {-value) }\end{array}$ \\
\hline $\boldsymbol{S}_{\boldsymbol{t}}$ & 26,11 & 25,84 & 1,03 & 0,054 & 0,095 \\
\hline $\boldsymbol{F}_{\boldsymbol{t}}$ & 26,11 & 25,85 & 1,02 & 0,079 & 0,085 \\
\hline $\boldsymbol{S}_{\boldsymbol{t}}-\boldsymbol{F}_{\boldsymbol{t}}(-3)$ & 0,04 & $-0,01$ & 0,674 & 0,000 & 0,000 \\
\hline $\boldsymbol{s}_{\boldsymbol{t}}=\log \left(\boldsymbol{S}_{\boldsymbol{t}}\right)$ & 3,261 & 3,252 & 0,039 & 0,057 & 0,092 \\
\hline $\boldsymbol{f}_{\boldsymbol{t}}=\log \left(\boldsymbol{F}_{\boldsymbol{t}}\right)$ & 3,261 & 3,254 & 0,039 & 0,082 & 0,082 \\
\hline $\boldsymbol{L o g}\left(\boldsymbol{S}_{\boldsymbol{t}}\right)-\log \left(\boldsymbol{F}_{\boldsymbol{t}}(-3)\right)$ & 0,00 & $-0,00$ & 0,026 & 0,000 & 0,000 \\
\hline
\end{tabular}

Source: Eviews output

Table 4. OLS linear regression $-\mathrm{p}$ values in brackets

\begin{tabular}{|c|c|c|c|c|c|c|}
\hline $\begin{array}{c}\text { Constant } \\
\text { (p-value) }\end{array}$ & $\begin{array}{c}\text { Linear } \\
\text { coefficient } \\
\text { (p-value) }\end{array}$ & $\begin{array}{c}\text { Durbin } \\
\text { Watson }\end{array}$ & $\begin{array}{c}\text { Prob } \\
\text { (F-statistic) }\end{array}$ & $\begin{array}{c}\text { Residuals } \\
\text { Jarque- Bera } \\
\text { prob. }\end{array}$ & $\begin{array}{c}\text { Residuals } \\
\text { Breusch-Godfrey } \\
\text { prob. }\end{array}$ & $\begin{array}{c}\text { Residuals Test } \\
\text { White prob. }\end{array}$ \\
\hline $0,009(0,0401)$ & $0,997(0,000)$ & $(0,18)$ & $(0,00)$ & $(0,52)$ & $(0,00)$ \\
\hline
\end{tabular}

Source: Eviews output

From the data features output, it is clear that the Czech FOREX Market financial instruments are appreciated. This evolution trend tempered with the Czech National Bank intervention in the 2013. The stochastic features are loosely speaking a bit suitable in the last ten years (Tab.3) than in the previous period before crisis 2008 (Tab.2). In the first half of the data sample, the Czech economy lied further from its equilibrium, so that there was greater dynamics and worse features of the time series in the way of stationarity and normality of the variables. Despite this, in the both sub-periods, we are not able to reject existence of the unit roots. The spot exchange and forward rate are even in their logarithms nonstationary. The linear regression approach is useless. $\mathrm{F}_{\mathrm{t}}(-3)$ represents the proper time lag. We used three-month forward rates. Moreover, we used quarterly transformed averages of daily data of spot exchange rates and the forward rates.

\section{Analysis - Linear Regression and Cointegration}

From the previous Tab. 1 it is clear that the standard OLS linear regression methods are useless even these methods would, for the first sight, provide useful coefficients (more in the Tab.2). For nonstationary time series, we expect so called spurious regression. We do see too high level of autocorrelation and not normal distributed residual, but suitable low level of heteroscedasticity in residuals. These all together confirm a strong relationship between forward rate and future spot exchange rate, which unfortunately we are not able to confirm using standard statistical methods.

Also from the Tab. 1, it is clear that the time series analyzed are both nonstationary. More we see that the evolution of the spot exchange rate and forward rate is very similar. Nonstationary time series can have the stationary common equilibrium (cointegration equation). Their residuals must be tested to be i.i.d (difference between the spot exchange rate and three months lagged forward rate). The descriptive statistics are calculated in the third row of the Tab.1. In the end the residuals time series are stationary. We see the null expected values of residuals, but we did observe not normality and autocorrelation in the residuals time series. Tab 4 Shows a hypothetical OLS regression with certainty a spurious regression.

Johansen cointegration test for nonstationary time series indicates total number of possible cointegration vectors. We did assume all trends stochastic. Under these assumptions, we confirm the existence of relationship between the two nonstationary time series analyzed. Johansen cointegration test all together with Trace test confirms one cointegration equation. This statement strengthens the economic fundaments of the MEH.

\section{Analysis - ARMA, VAR and Error Correction Method}

The problems described in the previous chapter lead us to use "more technically sophisticated" way of confirming/falsifying the MEH. These are according to Box-Jenkins methodology the Auto regression Moving Averages Method, Vector Auto Regression and Error Correction Method. In the simplest way we want to analyze the random part of the data series observed. It is much useful to explain the variable with its lagged values. This approach usually achieves higher degree of statistical significance. Despite this there is no reflection of empirics according to own lagged variables in the economic theory (comparative statics).

Our data sample provides the ARMA representation AR(1) MA (1). Further diagnosis of the residuals confirms 
the model quality (so do the impulse response diagram and the correlogram), the ARMA process is stationary and more invertible. Tab. 5 for whole data sample, Tab. 6 for pre-crisis horizon and Tab 7. For post-crisis horizon. ARMA statistical tests weaken the MEH hypothesis, because we create useful model without the forward rate variable. Moreover, we observed very strong linear dependence on the previous values so there are visible the stochastic trends in which the trading based on the technical analysis is successful. We need to highlight that the expected change in the mean value is the zero change, but the variance increases to the infinity values.

We observed that the ARMA structure of the spot exchange rate is similar in the Czech Republic in the two sub samples of the evolution. We divided the data sample before and after $2008 \mathrm{~m} 10$, the world financial crisis. There are major differences in these two subsamples.

At first, the autoregressive parameter is not so high $(0,913)$ and MA parameter is thus a bit higher after the world financial crisis started in the 2008 (Tab.7). It means that the linear dependence is a bit lower than before the crisis. We see that the options for trading on the spot exchange rates derivatives by the technical analysis are a bit lower. This fact could explain the more sophisticated regulation of the financial markets, its instruments, the higher capital reserves in the bank sector etc.

More from the economic perspective of the Czech Republic, we see that the nominal convergence stopped and after crisis the spot exchange rates value is not lowering its value (end of depreciation).

There was one major disadvantage in the previous ARMA analysis. According to the time series analysis, the logarithms of the spot exchange rates are still nonstationary. The times series is integrated in the first order of integration. In other words, first differences are of the spot exchange rates are stationary. This final time series is able to be analyzed according to the ARMA approach (ARIMA). The datasets are nonstationary, so the OLS and ARMA are not suitable and the results from those two models are not unfortunately meaningful.

Table 5. ARMA $(1,1)$ for the spot exchange rate whole data sample range 213 observations $-\mathrm{p}$ values in brackets

\begin{tabular}{|c|c|c|c|c|c|c|}
\hline $\begin{array}{c}\text { Constant } \\
\text { (p-value) }\end{array}$ & AR(1) term & MA (1) term & $\begin{array}{c}\text { Prob } \\
\text { (F-statistic) }\end{array}$ & $\begin{array}{c}\text { Durbin - } \\
\text { Watson }\end{array}$ & AR root \\
\hline $3,264(0,000)$ & $0,973(0,000)$ & $0,227(0,001)$ & $(0,000)$ & 1,98 & 0,973 \\
\hline
\end{tabular}

Source: Eviews output

Table 6. $\operatorname{ARMA}(1,1)$ for the spot exchange rate $-\mathrm{p}$ values in brackets $(2001 \mathrm{~m} 05$ to $2008 \mathrm{~m} 10)$

\begin{tabular}{|c|c|c|c|c|c|c|}
\hline $\begin{array}{c}\text { Constant } \\
(\mathbf{p}-v a l u e)\end{array}$ & AR(1) term & MA (1) term & $\begin{array}{c}\text { Prob } \\
\text { (F-statistic) }\end{array}$ & $\begin{array}{c}\text { Durbin - } \\
\text { Watson }\end{array}$ & AR root & MA root \\
\hline$-8,806(0,989)$ & $0,999(0,000)$ & $0,117(0,287)$ & $(0,000)$ & 1,99 & 0,999 \\
\hline
\end{tabular}

Source: Eviews output

Table 7. ARMA(1,1) for the spot exchange rate - p values in brackets (2008m10 to 2019m01)

\begin{tabular}{|c|c|c|c|c|c|c|}
\hline $\begin{array}{c}\text { Constant } \\
\text { (p-value) }\end{array}$ & AR(1) term & MA (1) term & $\begin{array}{c}\text { Prob } \\
\text { (F-statistic) }\end{array}$ & $\begin{array}{c}\text { Durbin - } \\
\text { Watson }\end{array}$ & AR root & MA root \\
\hline $3,265(0,000)$ & $0,913(0,000)$ & $0,297(0,001)$ & $(0,000)$ & 1,94 & 0,913 \\
\hline
\end{tabular}

Source: Eviews output

Table 8. ARIMA $(1,1)$ for the spot exchange rate whole data sample range 213 observations - $p$ values in brackets

\begin{tabular}{|c|c|c|c|c|c|c|}
\hline $\begin{array}{c}\text { Constant } \\
\text { (p-value) }\end{array}$ & AR(1) term & MA (1) term & $\begin{array}{c}\text { Prob } \\
\text { (F-statistic) }\end{array}$ & $\begin{array}{c}\text { Durbin - } \\
\text { Watson }\end{array}$ & AR root \\
\hline$-0,0013(0,226)$ & $0,1416(0,628)$ & $0,0904(0,758)$ & $(0,0038)$ & 1,99 & 0,1416 \\
\hline
\end{tabular}

Source: Eviews output

Table 9. ARIMA(1,1) for the spot exchange rate - p values in brackets (2001m05 to 2008m10)

\begin{tabular}{|c|c|c|c|c|c|}
\hline $\begin{array}{c}\text { Constant } \\
\text { (p-value) }\end{array}$ & AR(1) term & MA (1) term & $\begin{array}{c}\text { Prob } \\
\text { (F-statistic) }\end{array}$ & $\begin{array}{c}\text { Durbin - } \\
\text { Watson }\end{array}$ & AR root \\
\hline$-0,0037(0,012)$ & $-0,789(0,000)$ & $0,978(0,000)$ & $(0,029)$ & 1,99 & 0,789 \\
\hline
\end{tabular}

Source: Eviews output

Table 10. ARIMA(1,1) for the spot exchange rate - p values in brackets $(2008 \mathrm{~m} 10$ to $2019 \mathrm{~m} 01)$

\begin{tabular}{|c|c|c|c|c|c|}
\hline $\begin{array}{c}\text { Constant } \\
\text { (p-value) }\end{array}$ & AR(1) term & MA (1) term & $\begin{array}{c}\text { Prob } \\
\text { (F-statistic) }\end{array}$ & $\begin{array}{c}\text { Durbin - } \\
\text { Watson }\end{array}$ & AR root \\
\hline $0,0004(0,8068)$ & $0,1006(0,7503)$ & $0,189(0,5431)$ & $(0,0076)$ & 1,99 & 0,1006 \\
\hline
\end{tabular}

Source: Eviews output 
In this ARIMA approach we modelled first differences of the time series logarithms. Interpretations of these values are in economic field very common; these are the logarithmic (continuous) returns. From the following output (Tab. 8-11) we see that according to the pure statistic point of view, we highlight the model ARIMA in the data sample of pre-crisis period (Tab. 9). In the whole range and also in the post-crisis period, there are not sufficient values of the coefficient p-values, although model at all has sufficient F-statistics. Model provides a good level of admired features for residuals (normality, non-autocorrelation, heteroscedasticity) but through differentiation we lost many information, therefore the ARIMA coefficient individually are insignificant.

Previous results are very common. When we want to go ahead a perfect model according to the statistic theory, we usually lost information from the data and more the results lost any economic interpretation. In the econometric point of view, there is highlighted the data interpretation which has economic sense even when there may appear a loss in the statistical clarity. According to this approach, we confirm our results from the ARMA analysis; anyway main conclusions are the same. ARIMA output is in this point of view useless.

In contemporary economic theory, we usually do not use sophisticated methods to explain dynamics in the economic variables. We need to help ourselves with the theory of time series. Despite the economic theory, in empirical consequences, it is frequent that the variables are both endogenous. These variables are influencing themselves without any sense of causality. The Vector Auto Regression (VAR) analysis assumes that all the variables are endogenous. This approach models the influence of shock as a whole not particularly. In the following analysis we would like to rehabilitate the MEH hypothesis, in which the forward rate is included.

At first, we tried several VAR models different due to the lag structure. The output was always similar for the first sight. Both coefficients in the spot exchange rates and forward rates (in logarithms, because VAR approach assumes the stationary time series) were achieved with no such efficient standard errors and t-statistics. In the further diagnosis, we prove the VAR approach to be useful. It is expected due to the fact that it is extension of the ARMA approach. We must decide whether or not the concretized VAR model is stationary. From the table (graph) of the AR roots, we concluded that all the roots lie inside the unit circle. This is the condition needed for further impulse - response diagnosis.

From the lag exclusion tests, we excluded the lag in the level of three. The previous statement is bit dampened due to output of the lag length criteria (Akaike information criterion, Schwarz information criterion) so we made few tests for VAR residuals (Portmanteau Autocorrelation Test, Autocorrelation LM Test, Normality tests and White Heteroscedasticity Tests). We confirmed the original statement about the final lag length of VAR to the max level of two months (the VAR residuals are then normal, not auto correlated but with a significant heteroscedasticity).

Impulse - Response diagnosis provided the effects of shocks to the variable. This shock is through the dynamic lag system extended to the other endogenous variables. When we follow the original aim to divide the data sample with the $2008 \mathrm{~m} 09$, we saw that before the crisis we were unable to create stable VAR model of the spot exchange rate and the $3 \mathrm{M}$ previous forward rate. One root lied outside the unit circle. This statement confirms the ARMA conclusion about the spot exchange rate evolution before crisis.

(Vector) Error Correction (EC) models are used for nonstationary time series, at which we know they are cointegrated. For our purposes, in which we confirmed nonstationary time series and more their common equilibrium is stationary we are able to run the (V)EC method. EC models restrict the long run behaviour of the endogenous variables to be limited and converged according to cointegration relationship. In the other words, Error Correction models provide as a first step the cointegration equation (7) which is corrected with the VAR of correction term (8)

$$
\begin{gathered}
y_{2, t}=\beta y_{1, t} \\
\Delta y_{1, t}=\alpha_{1}\left(y_{2, t-1}-\beta y_{1, t-1}\right)+\varepsilon_{1, t} \\
\Delta y_{2, t}=\alpha_{2}\left(y_{2, t-1}-\beta y_{1, t-1}\right)+\varepsilon_{2, t}
\end{gathered}
$$

Need to say that we assume no lag in the correction term. Finally, there is only cointegration correction not lagged. The previous is explainable thanks to the fact that financial variables are usually not following the adaptive expectations but the rational view.

The (V)EC output from the data sample is:

$$
\begin{gathered}
y_{2, t}=-1,01 y_{1, t} \\
\Delta y_{1, t}=0,828\left(y_{2, t-1}-\beta y_{1, t-1}\right)+\varepsilon_{1, t} \\
\Delta y_{2, t}=0,872\left(y_{2, t-1}-\beta y_{1, t-1}\right)+\varepsilon_{2, t}
\end{gathered}
$$

In this model, all the coefficients are statistically significant. They achieve low standard errors and relatively high t-statistics (the p-values confirm rejection of the null hypothesis about the coefficients to be zero). The potential constant has its own explanation with the existence of the transaction costs in the FOREX market (its value is the $4 \%$ ).

In case we divide the whole data sample into two parts according the financial crash in $2008 \mathrm{~m} 09$, we achieve following (V)EC data sample (tab 11.). We observed that the VEC representation in two sub samples is a bit different. The most interesting difference is in the cointegration equation. From the MEH we assumed the 
value of unity and zero constant. In both two subsamples the forward rate achieved the approximately unity value (before 2008m09 it is a bit lower than unity and vice versa. Despite this, the negative constant has no economic sense in the way of transaction cost. In the long run, the dynamics of the spot exchange rates-the forward rates provides more expectable features. But, these features are still very different from the MEH hypothesis in its weak form, in which the forward rate should serve as an unbiased predictor of the future spot exchange rates.

Table 11. $\operatorname{VEC}(0,0)$ for the spot exchange rate and forward rate $-p$ values in brackets

\begin{tabular}{|c|c|c|c|c|c|}
\hline $\begin{array}{c}\text { Data } \\
\text { sample }\end{array}$ & $\begin{array}{c}\text { Cointegration } \\
\text { Equation }\end{array}$ & $\alpha_{1}$ & $\alpha_{2}$ & $\begin{array}{c}\alpha_{1} \\
\text { F-stat. }\end{array}$ & $\begin{array}{c}\alpha_{2} \\
\text { F-stat. }\end{array}$ \\
\hline $\begin{array}{c}2001 \mathrm{~m} 05 \\
\text { to }\end{array}$ & $\begin{array}{c}Y_{2, t}=+ \\
0,98 * Y_{1, t}+ \\
0,069\end{array}$ & 2,298 & 2,408 & 5,256 & 5,803 \\
\hline $\begin{array}{c}2008 \mathrm{~m} 09 \\
\begin{array}{c}200 \mathrm{~m} 09 \\
\text { to } \\
2019 \mathrm{~m} 01\end{array}\end{array}$ & $\begin{array}{c}Y_{2, t}= \\
+1,027 * Y_{l, t} \\
-0,089\end{array}$ & 1,213 & 1,309 & 3,737 & 4,427 \\
\hline
\end{tabular}

Source: Eviews output

\section{Conclusions}

The aim of this paper was to evaluate the Market Efficiency Hypothesis on the FOREX market in its weak form. This is about that the current prices fully reflect all the past information. No arbitrary equilibrium assumption derives the spot exchange dynamics as the difference between foreign and domestic investors. This is complexly described using the (un)covered interest rates parity conditions. These conditions lead to the so-called Fama's equation about forward rate to be the unbiased predictor of the future spot exchange rate. On the data sample of 2014 observations from the 2001 to 2019 , we run few statistical tests to confirm/reject the hypothesis. We are not able to use the standard linear regression approach because the solution did not fit the standard Gauss - Markov Assumption. More we run ARMA $(1,1)$ and VAR models, which confirm that the spot exchange rate and forward rate are more dependent on its own lagged values than on themselves. We run a full diagnosis in Eviews software (AR roots, impulse- response diagrams). This diagnosis fully confirms the previous concluded remarks.

Let's make a few conclusion remarks. The main goal was to confirm whether or not the market efficiency hypothesis (MEH) is suitable on the data sample of the Czech Republic FOREX market (CZK/EUR). The interest rates parity conditions evolve the forward rate as the unbiased predictor of future spot exchange rate. The OLS and ARMA methods are not suitable due to nonstationary time series. ARIMA approach seems to be proper method using the modified data and model the relationship with autoregression term and moving averages term. It shows that the best predictor of the current value of exchange rate is its previous value. Coefficients are not proper due to transformation data into integrated time series.

The MEH hypothesis expects that the price of financial asset fully reflects all the past information. The ARIMA approach confirms the hypothesis in the form of martingale behavior. The residuals are not i.i.d. but residuals are stable in the long run (long period view). This conclusion is confirmed with the VEC model. This conclusion remark fits to the literature most empirical tests for UIP. C-CAPM approach for FOREX market is being tested in the other papers of author. But this test provides useless conclusions due to additional macro-finance relationships.

All conclusions made are reasoned on the fact that the FOREX market variables are nonstationary. So we must finally utilize the times series analysis for the nonstationary time series. These are the cointegration approach and the Vector Error Correction Method. These two methods confirm stochastically stable equilibrium between spot exchange and lagged forward rate, but, with the not lagged correction term. In the end, we have to reject the Fama's equation (Interest rates parity condition) in its original view (even the weak form) but there is a strong long run relationship between analyzed variables. In the short run, there is a significant influence of random effects. More there is a difference, in which it is explained the effect of transaction costs or the FOREX risk premium. The problem is technically solvable thanks to nonlinear equilibrium adjustments. More we theoretically described explanation of the puzzle thank to representative agent model C-CAPM. By product of this paper is conclusion about fundamental analysis being useless in the FOREX trading in the short run (more probably even long run) in contrary with the technical analysis trying to avoid stochastic trends as a basis for trading. The spot exchange rate follows martingale behavior. The best future estimation is its current value. It does not refer the same to the Market Efficiency Hypothesis (MEH).

\section{REFERENCES}

[1] Abreu, D., Brunnermeier, M. K. "Bubbles and Crashes," Econometrica, vol. 71, no.1, pp.173-204. 2003. https://doi.org/10.1111/1468-0262.00393

[2] Aiyagari, S., Gertler, M. "Overreaction" of Asset Prices in General Equilibrium, Review of Economic Dynamics, vol. 2, no. 1, pp. 3-35. 1999. https://doi.org/10.1006/redy.1998. 0053

[3] Baillie, R. T., Bollerslev, T. "The forward premium anomaly is not as bad as you think," Journal of International Money and Finance, vol. 19, no.4, pp. 471-488. 2000. https://doi.org/10.1016/s0261-5606(00)00018-8.

[4] Bernanke, B. S., Gertler, M. "Agency costs, collateral, and business fluctuations," NBER. 1986 
https://doi.org/10.1086/654081

[5] Betts, C., Devereux, M. B. "Exchange rate dynamics in a model of pricing-to-market," Journal of International Economics, vol. 50, no. 1, pp. 215-244. 2000. https://doi.org/10.1016/s0022-1996(98)00036-1

[6] Canova, F., Ito, T. "The time-series properties of the risk premium in the Yen/Dollar exchange market," Journal of Applied Econometrics, vol. 6, no. 2, pp. 125-142. 1991 https://doi.org/10.1002/jae.3950060203

[7] Cochrane, J. H. “Asset pricing: Revised edition,” Princeton university press. 2009.

[8] Cuthbertson, K., Nitzsche, D. "Quantitative financial economics: stocks, bonds and foreign exchange," John Wiley \& Sons. 2006.

[9] Fama, E. F. "Forward and spot exchange rates," Journal of Monetary Economics, vol. 14, no.3, pp. 319-338. 1984. https://doi.org/10.1016/0304-3932(84)90046-1

[10] Fama, E. F. "Forward rates as predictors of future spot rates," Journal of Financial Economics, vol. 3, no.4, pp. 361-377. 1976. https://doi.org/10.1016/0304-405x(76)90027-1

[11] Hansen, L. P., Jagannathan, R. "Implications of Security Market Data for Models of Dynamic Economies," Journal of Political Economy, vol. 99, no.2, pp. 225-262. 1991. https://doi.org/10.1086/261749

[12] Hansen, L. P., Hodrick, R. J. "Forward Exchange Rates as Optimal Predictors of Future Spot Rates: An Econometric Analysis," Journal of Political Economy, Vol. 88, No. 5, pp. 829-853. 1980. https://doi.org/10.1086/260910

[13] Hamilton, J. D. “Time series analysis (Vol. 2)," Princeton: Princeton university press. 1994

[14] Hau, H. "Exchange rate determination: The role of factor price rigidities and nontradeables," Journal of International Economics, vol. 50, no.2, pp. 421-447. 2000. https://doi.org/10.1016/s0022-1996(99)00002-1

[15] Kočenda, E., \& Moravcová, M. "Exchange rate comovements, hedging and volatility spillovers on new EU forex markets," Journal of International Financial Markets, Institutions and Money, vol. 58, pp. 42-64. 2019. https://doi.org/10.1016/j.intfin.2018.09.009

[16] Kočenda, E., Poghosyan, T. "Macroeconomic sources of foreign exchange risk in new EU members." Journal of Banking \& Finance, vol. 33, no. 11, pp. 2164-2173. 2009. https://doi.org/10.1016/j.jbankfin.2009.05.015
[17] Londono, J. M., Zhou, H. "Variance risk premiums and the forward premium puzzle," Journal of Financial Economics, vol. 124, no. 2, pp. 415-440. 2017. https://doi.org/10.1016/j.jfineco.2017.02.002

[18] Lintner, J. “SECURITY PRICES, RISK, AND MAXIMAL GAINS FROM DIVERSIFICATION," The Journal of Finance, vol. 20, no. 4, pp. 587-615. 1965. https://doi.org/10.1111/j.1540-6261.1965.tb02930.x

[19] Lucas, R. E. "Asset Prices in an Exchange Economy," Econometrica, vol. 46, no.6, pp. 1429. 1978. https://doi.org/10.2307/1913837

[20] Lütkepohl, H. "New introduction to multiple time series analysis," Cambridge University Press. Cambridge. 2005

[21] Lyons, R. K. "The microstructure approach to exchange rates," MIT press. Cambridge. 2001

[22] Makovský, P. Market Efficiency Hypothesis Application in the Czech Republic - the FOREX Case. International Day of Statistics and Economics. Prague. 2019.

[23] Markowitz, H. "PORTFOLIO SELECTION," The Journal of Finance, vol. 7, no. 1, pp. 77-91. 1952. https://doi.org/10.1111/j.1540-6261.1952.tb01525.x.

[24] Mehra, R., Prescott, E. C. "The equity premium: A puzzle," Journal of Monetary Economics, vol. 15, no. 2, pp. 145-161. 1985 .https://doi.org/10.1016/0304-3932(85)90061-3.

[25] Moh, Y. K. "Exchange rate dynamics in a continuous-time model of uncovered interest parity and the regulated jump-diffusion interest differential," unpublished working paper, Tulane University. 2002

[26] Mossin, J. "Equilibrium in a Capital Asset Market," Econometrica, vol. 34, no. 4, pp. 768. 1966. https://doi.org/10.2307/1910098

[27] Pástor, U., Veronesi, P. "Technological Revolutions and Stock Prices," American Economic Review, vol . 99, no. 4, pp. 1451-1483. 2009. https://doi.org/10.1257/aer.99.4.1451

[28] Teräsvirta, T. "Specification, Estimation, and Evaluation of Smooth Transition Autoregressive Models," Journal of the American Statistical Association, vol. 89, no. 425, pp. 208 218. 1994. https://doi.org/10.1080/01621459.1994.104764 62

[29] Tobin, J. "Liquidity Preference as Behavior Towards Risk,". The Review of Economic Studies, vol. 25, no. 2, pp. 65. https://doi.org/10.2307/2296205

[30] Wickens, M. "Macroeconomic Theory: A dynamic general equilibrium approach,” Princeton University Press. 2012 